\title{
Trust and Risk in Purchase Intention through Online Social Network: A Focus Group Study of Facebook in Thailand
}

\author{
A. Leeraphong and A. Mardjo
}

\begin{abstract}
Objectives: Doing business through online social network is influenced by factors that might be differed compared with doing business through normal ecommerce channel. Although previous studies have been conducted to determine some of these factors which are affecting online purchase intention in social media website, little research exists with respect to the study regarding trust and risk in online social network. This research is one of the studies that use a focus group study among working adult (ages 25 to 34), to explore preliminary research model and hypotheses that had been gathered from the literature reviews regarding trust and risk that influence their online purchase decision through online social network, particularly Facebook. Results: The findings of factors and their attributes from this study are in line with the findings in the literature. The differences mainly come from details of the descriptions and expressions of each attribute.
\end{abstract}

Index Terms-Social network, subjective norm, trust, risk, past online purchase experience.

\section{INTRODUCTION}

Searching, browsing, and purchasing a product on ecommerce websites can be a time consuming and frustrating task for consumers. More than $80 \%$ of online shoppers have at certain point left ecommerce websites without getting what they want [1]. Richer ecommerce systems, such as web-based personalized recommender systems, enable companies to enhance their customers' decision making and their bottom line [2]. Nevertheless, Sinha and Swearingen [3] found that consumers prefer to accept recommendations from people they acquainted with and trust, such as friends and family-members, rather than from web-based recommender systems.

Online social network (OSN) allows the users to share information to their friends or families which could be browsed by many people and lead to many to many spread of information. The power of the social network has pushed the businesses to use social media as a platform to conduct ecommerce. According to Evans [4], social media is blooming now and businesses should participate in it as many people around the world are connecting to each other and discussing about their company and products through this media. Furthermore, he stated that it will be a loss for

Manuscript received January 30, 2013; revised April 2, 2013. This work was supported by Prince of Songkla University, Trang Campus.

The authors are with the Prince of Songkla University, Trang Campus, Trang, 92000 Thailand (e-mail: atchara.1@ psu.ac.th, anny.m@ psu.ac.th). companies if they choose to ignore their customers' comments in the social media and choose not to participate. While many marketers acknowledge the importance of using the OSN in their marketing mixes, only a few researchers has studied what factors which influence customer purchase decision through OSN. Most previous studies were based on Technology Acceptance Model (TAM). Thus, there is a gap in the literature surrounding factors which influence customer purchase decision through OSN explained on different theories. In addition, this study is significant as it can be used by business for winning the business potential on the Internet environment by having a better understanding of social network based interaction.

According to research by Nielsen (2011) in Table I, there are 14,235,700 Facebook users in Thailand, thus it made Facebook the most popular OSN in Thailand. FB penetration in Thailand is $21.42 \%$ compared to the country's population and $81.33 \%$ in relation to number of Internet users (Table II). $81.33 \%$ of Internet users which can become potential consumers are hard to ignore which makes FB particularly a good OSN to market the products.

TABLE I. SOCIAL MEDIA UsAGE IN THAILAND YEAR 2011 (ADAPTED FROM NIELSEN, 2011)

\begin{tabular}{ll}
\hline \hline Social Media & No. of people \\
\hline Facebook & $14,235,700$ \\
Hi5 & $2,611,000$ \\
Twitter & 720,000 \\
Linkedin & 295,000 \\
Foursquare & 152,000 \\
\hline \hline
\end{tabular}

TABLE II: THAILAND FACEBOOK STATISTIC (ADAPTED FROM SOCIALBAKERS, 2012)

\begin{tabular}{ll}
\hline \hline Measure & $\%$ \\
\hline Facebook penetration of population & 21.42 \\
Facebook penetration of online population & 81.33 \\
\hline \hline
\end{tabular}

The purpose of this research was to develop a theoretical model which integrates risk, trust, subjective norm and past online purchase experience of the factors that influence purchase intention of working adult (ages 25 to 34) consumers through FB. As this research problem has not previously been studied in Thailand, the study began with a literature review of previous studies on related subjects, in order to develop a theoretical model for this study. It is closely followed by an exploratory study conducted to generate working adult consumer insight and to refine and explore additional factors, attitudes and intentions toward the online purchase through FB. 


\section{THEORETICAL BACKGROUND}

\section{A. Risk and Perceive Risk}

Risk entails a degree of uncertainty and the consequences that are associated with each course of alternative. In addition, each alternative will differ in the degree of perceived risk. Theoretically, an individual will choose the alternative that generates the most favorable outcome. Compared with traditional shopping, online purchase is perceived by consumers as more risky and this can be an obstacle for consumers' motivation for online purchase [5].

Furthermore, risk can be defined as the subjectivelydetermined loss expectation by an online consumer in contemplating a particular online purchase [6]. The perceived risks that are identified include financial, product performances, social, psychological and time convenience loss [5], [6]. If the consumer perceives the level of risk associated with purchasing a product or service as too high, he/she will not complete the transaction. The consumer may initiate risk-reducing behaviors to account for the high levels of perceived risk. The risk-reducing behaviors may either reduce the amount at stake or reduce the perceived uncertainty of the situation.

Two main reasons for including perceive risk in this research. First, purchasing product through FB is considered risky as there is not specific guidelines requirement to be a seller in FB. Second, there are no buyer protections if the sellers did not fulfill what they have promised to the buyers.

\section{B. Trust}

According to Blau [7], trust can reduce uncertainty created by other people or artifacts and is therefore essential for ecommerce. It has been shown to affect consumers' fears of unreliability and risks of being cheated. Trust in the online environment is particularly important because of the complexity and diversity of online interactions and the resulting possibility of insincere and unpredictable behavior [8]. Kim and Bensabat [9] claimed, in an online shopping context, consumers are vulnerable and likely to expose themselves to loss if they: (i) provide the email address (with the vulnerability of spam email); (ii) provide their shipping information (with the vulnerability of privacy invasion); (iii) provide their credit card information (with the vulnerability of credit card fraud) or (iv) complete online purchase transaction (with the vulnerability to quality and service inadequate).

In the context of OSN such as FB, there are several reasons why trust is an important factor in the online purchase intention. First, FB users must provide personal information when they register to FB. Such personal information is subject to potential abuse as the data might be used for marketing purposes or shared with third parties. Thus, users may have concerns about the misuse of their personal information done by FB. Second, there are unclear security settings (such as https, SSL, or third party certificate) in FB. Therefore, consumers must trust either FB or OSN vendor not to violate their privacy and security. Finally, anybody can open a shop in FB as long as they are registered member. Therefore, buyers may have concerns about whether the sellers are reliable.

\section{Subjective Norm}

Subjective norm or social influence is the degree of a person's perception that people who are important to him or her think he or she should or should not perform the behavior in question [10]. It is related to intention because people often act based on their perception of what others think they should do. In the context of purchasing intention in social media settings, it means that a person can be influenced by someone who is important to him or her who think he or she should perform or not to perform the transaction online. Since this study is conducted in the context of social media, subjective norm would be an important influencing factor as social influence among users is very high in the social media website.

\section{Past Online Shopping Experience}

Based on the previous study [11], intention to shop online is related to internet shopping history and has a direct impact on internet shopping behavior. Customers with strong online purchase intention in web shopping usually have prior purchase experiences that assist in reducing their uncertainties [12].

The main reason that past online purchase experience included in this study because FB is another online shopping channel even though its original purpose is a social network. There are more risks and trust involved in the social network compared to normal ecommerce website when the customers purchasing products. Thus, it will be interesting to know whether users' confidence and skills in online effect can overcome those trust and risks.

\section{RESEARCH MODEL AND HYPOTHESES}

\section{A. Preliminary Model and Hypothesis}

Through analyzing the existing literature, we propose a conceptual model that combines the four new constructs that capture the uniqueness of the online purchase intention through social network namely, risk, trust, subjective norm and past online shopping experience.

Reliability or riskiness can be implied as the degree of uncertainty surrounding the outcome of an innovation [13].Based on the study done by van der Heidjen, Verhagen and Creemers [14], perceived risk has a significant negative impact toward adoption. Thus, it is expected that only individuals who perceive using FB to purchase products as a low risk undertaking would be inclined to adopt it. This leads to the hypothesis:

H1: Perceived risk negatively affects the online purchase intention (PI) through FB.

Kim and Benbasat [9] stated that trust helps the complexity and vulnerability a consumer feels while engaging in ecommerce by allowing the consumer to subjectively rule out undesirable yet possible behaviors of the online vendor. Therefore, trust helps consumers reduce their risk perceptions when dealing with online vendors [14] makes them more comfortable sharing their personal information which is necessary in ecommerce transactions. Consumer trust in a company's website has been shown to directly and positively affect the attitude toward the 
company and purchase intention from that company [14]. Based on the arguments above, we propose as in Fig. 1:

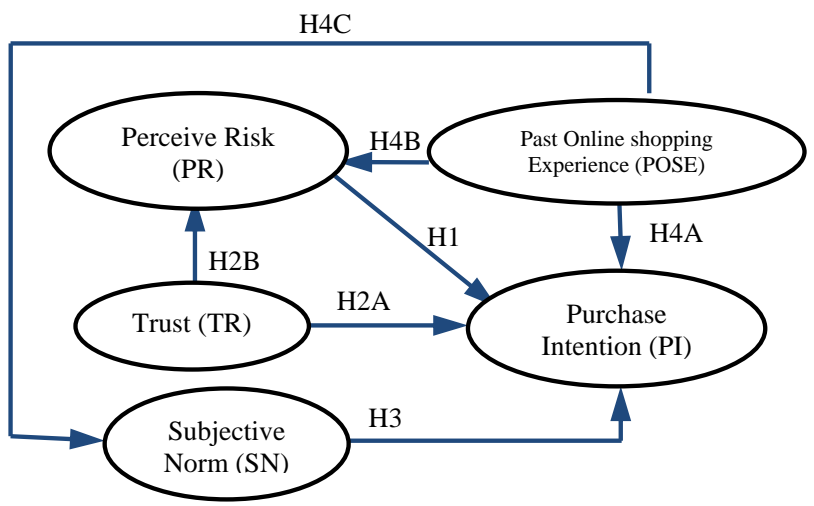

Fig. 1. Preliminary model.

H2A: A consumer's trust (TR) positively affects the consumer's intention to purchase (PI).

H2B: A consumer's trust (TR) negatively affects the consumer's perceived risk (PR) of a transaction.

The direct influence of subjective norm on intention has mixed results with Taylor and Todd [15] found significant effect of subjective norm on intention, while Mathieson [16] found no significant effect. According to Taylor and Todd [15], subjectively norms positively influence intention in the early stages of implementation of technology and as the usage of social network for online shopping is relatively new, we will assume that subjective norm will positively influence intention. This leads to the hypothesis:

H3: Subjective norm positively affects the purchase intention through FB.

Ranganathan and Jha [17] claimed that past online shopping experience has the strongest association with purchase intention compared to other factors in their models. Thus the hypothesis:

H4A: A consumer's past online online experience (POSE) positively affects the consumer's intention to purchase (PI).

In case prior online shopping experiences resulted in satisfactory outcomes and were judged positively, it leads consumers to continue to shop on the Internet in the future [18]. Such past experiences decrease consumers' perceived risk levels associated with online shopping. Furthermore, trust increases when expectations of the other party are consistently and reliably met, and decreases when the other party acts otherwise [7]. Therefore, we hypothesize:

H4B: A consumer's past online shopping experience (POSE) negatively affects the consumer's perceived risk (PR) of a transaction.

H4C: A consumer's past online shopping experience of purchasing products from Facebook. (POSE) positively affects the consumer's trust (TR) of a transaction.

\section{ANALYSIS AND FINDINGS}

The focus group respondents of this research were 15 working adults aged between 25-34 years old. Characteristics of the respondents are summarized in Table III.
TABLE III: FOCUS GROUP DEMOGRAPHIC

\begin{tabular}{|c|c|c|}
\hline Measure & Items & $\%$ \\
\hline \multirow[t]{2}{*}{ Gender } & Male & 46.67 \\
\hline & Female & 53.33 \\
\hline \multirow[t]{2}{*}{ Age (years) } & $25-29$ & 26.67 \\
\hline & $30-34$ & 73.33 \\
\hline \multirow[t]{3}{*}{ Marital Status } & Single & 73.33 \\
\hline & Married without children & 0 \\
\hline & Married with children & 26.67 \\
\hline \multirow[t]{3}{*}{ Times per week using Internet } & $1-2$ & 0 \\
\hline & $3-4$ & 0 \\
\hline & $>4$ & 100 \\
\hline \multirow[t]{2}{*}{ Years of Internet experience } & $1-2$ & 0 \\
\hline & $>2$ & 100 \\
\hline \multirow[t]{3}{*}{ Times per week using FB } & $1-2$ & 0 \\
\hline & $3-4$ & 13.33 \\
\hline & $>4$ & 86.67 \\
\hline \multirow[t]{2}{*}{ Years of FB experience } & $1-2$ & 20 \\
\hline & $>2$ & 80 \\
\hline
\end{tabular}

\section{DISCUSSION AND INTERPRETATIONS}

Most respondents in the focus group believed trust in the online retailer influenced their' perceived risk of transaction and their intention to conduct a transaction. They were more likely to purchase the product from that FB seller if they believed that the seller was capable of providing a secure purchase environment and good quality service. Personal information collected during the shopping process that was disclosed in FB were particularly caused the concern for the respondents as they did not know how secure FB was and how FB would use their data. For example, online consumers are required to share personal detail (such as mailing address, telephone number), financial information (such as payment detail information).

Respondents felt there was little assurance from FB sellers that they will receive the products comparable to the ones they ordered according to the description and image on the computer screen. Thus, they experienced risk of products or services not matching the description on the website and the risk of damage during the delivery process, etc.

Most respondents listed subjective norm as the least important factor that will affect their purchase intention. Nevertheless, social pressure influenced their trust with the Facebook seller and the way they perceived the advantages.

There were mixed results for the effect of frequency of online shopping and the comfort of online shopping with the purchase intention through Facebook. The frequency and comfort of online shopping did not encourage some respondents to purchase product through Facebook. It might be caused by other factors that were more important for them, such as trust and perceived risk. Nevertheless, some respondent admitted that their past online purchase contributed to their assumption of perceived risk in purchasing product from Facebook.

Both female and male respondents agreed that the result of online purchase done by other people will affect their buying decisions. If the comments regarding the sellers or 
the products were positive, they were more likely to purchase the product from that seller. On the other hand, negative comments would discourage them to buy the products from that seller. The respondent who joined FB group will see the comments based on the group members regarding a particular seller before they continue with their purchase. Based on these, it is clearly shows that consumers in FB try to reduce levels of uncertainty which can affect trust and risk by seeking more information from past experiences of others. Word of mouth can be defined as the favorability of indirect information about online purchasing from the customer's social network and relations, either offline and online [25], [26]. In this case, online word of mouth is in the form of experiences dealing with seller that were posted by prior customers in their online social network. The word of mouth refers the influence of both positive and negative referrals. Prospective customers can have some social contacts providing positive referrals while others provide negative concurrently [20]. According to Kuan and Bock [20], word of mouth significantly affects online trust. Attributes of trust, risk, subjective norm, past online purchase experience, online word of mouth based on the focus group are summarized in Table IV.

TABLE IV: VARIABLES OF EACH FACTOR MENTIONED By FOCUS GROUPS

\begin{tabular}{|c|c|c|c|}
\hline Factor & Attributes & $\begin{array}{c}\text { Lit. } \\
\text { Review }\end{array}$ & Ref. \\
\hline Trust & $\begin{array}{l}\text { Products or services purchased by } \\
\text { using Facebook will be } \\
\text { trustworthy } \\
\text { The seller is reliable } \\
\text { Seller is committed to send the } \\
\text { product after payment }\end{array}$ & $\begin{array}{l}\sqrt{ } \\
\sqrt{ }\end{array}$ & [19] \\
\hline $\begin{array}{l}\text { Perceived } \\
\text { Risk }\end{array}$ & $\begin{array}{l}\text { Lose money } \\
\text { Did not receive goods } \\
\text { Afraid of being cheated } \\
\text { Safety } \\
\text { Product not as good as expected } \\
\text { Difficult to return goods } \\
\text { Do not get the right product } \\
\text { No warranty } \\
\text { Not confident } \\
\text { Do not dare to give credit card } \\
\text { info. } \\
\text { Products nearly expired } \\
\text { No guarantee }\end{array}$ & $\begin{array}{l}\sqrt{ } \\
\sqrt{ } \\
\sqrt{ } \\
\sqrt{ } \\
\sqrt{ } \\
X \\
\sqrt{ } \\
X \\
X \\
\sqrt{ } \\
\\
\text { V } \\
X\end{array}$ & $\begin{array}{l}{[2,20,} \\
21]\end{array}$ \\
\hline $\begin{array}{l}\text { Subjective } \\
\text { Norm }\end{array}$ & $\begin{array}{l}\text { Most of my friends and } \\
\text { acquaintances think that buy } \\
\text { products through this Facebook } \\
\text { seller is a good idea } \\
\text { Most of my families think that } \\
\text { buy products through this } \\
\text { Facebook seller is a good idea. } \\
\text { Most people in my social network } \\
\text { want me to buy products from } \\
\text { Facebook. }\end{array}$ & $\sqrt{ }$ & [22] \\
\hline $\begin{array}{l}\text { Past Online } \\
\text { shopping } \\
\text { experience }\end{array}$ & $\begin{array}{l}\text { Frequency of online shopping } \\
\text { Comfort of online shopping }\end{array}$ & $\begin{array}{l}\sqrt{ } \\
\sqrt{ }\end{array}$ & {$[23,24]$} \\
\hline $\begin{array}{l}\text { Online } \\
\text { Word of } \\
\text { Mouth }\end{array}$ & $\begin{array}{l}\text { Can see other people have } \\
\text { received the product. } \\
\text { Can see other peoples' comments } \\
\text { about the received product. } \\
\text { Can see other peoples' comments } \\
\text { about the seller. }\end{array}$ & $\mathrm{X}$ & \\
\hline
\end{tabular}

Based on the focus finding and literature review, we will add word of mouth as another construct for the preliminary model (Table V and Fig. 2).
TABLE V: CONSTRUCTS AND THEIR RELATIONSHIPS

\begin{tabular}{|c|c|c|c|c|}
\hline \multicolumn{2}{|r|}{ Hypothesis } & \multirow{2}{*}{$\frac{\begin{array}{c}\text { Lit. } \\
\text { Review }\end{array}}{\sqrt{ }}$} & \multirow{2}{*}{$\begin{array}{l}\text { Ref. } \\
{[14]}\end{array}$} & \multirow{2}{*}{$\begin{array}{c}\text { Focus } \\
\text { Group }\end{array}$} \\
\hline H1 & $\begin{array}{l}\text { Perceived Risk (PR) } \rightarrow \text { Purchase } \\
\text { Intention (PI) }(-)\end{array}$ & & & \\
\hline $\mathbf{H} 2$ & $\begin{array}{l}\text { Trust (TR) } \rightarrow \text { Purchase Intention } \\
\text { (PI) }\end{array}$ & $\sqrt{ }$ & [14] & $\sqrt{ }$ \\
\hline H2B & Trust (TR) $\rightarrow$ Perceived Risk (PR) & $\sqrt{ }$ & [14] & $\sqrt{ }$ \\
\hline H3 & $\begin{array}{l}\text { Subjective Norm (SN) } \rightarrow \text { Purchase } \\
\text { Intention (PI) }\end{array}$ & $\sqrt{ }$ & [15] & $\sqrt{ }$ \\
\hline H3B & $\begin{array}{l}\text { Subjective Norm (SN) } \rightarrow \text { Trust } \\
(\mathrm{TR})\end{array}$ & & & $\sqrt{ }$ \\
\hline H3 & $\begin{array}{lll}\text { Subjective } \quad \text { Norm } & (\mathrm{SN}) & \rightarrow \\
\text { Perceived Risk (PR) } & & \end{array}$ & & & $\sqrt{ }$ \\
\hline H4 & $\begin{array}{l}\text { Past Online Shopping Experience } \\
(\mathrm{POSE}) \rightarrow \text { Purchase Intention (PI) }\end{array}$ & $\sqrt{ }$ & [17] & $\sqrt{ }$ \\
\hline H4B & $\begin{array}{l}\text { Past Online Shopping Experience } \\
(\text { POSE) } \rightarrow \text { Perceived Risk (PR) }\end{array}$ & $\sqrt{ }$ & {$[18]$} & $\sqrt{ }$ \\
\hline H4 & $\begin{array}{l}\text { Past Online Shopping Experience } \\
(\text { POSE) } \rightarrow \text { Trust (TR) }\end{array}$ & $\sqrt{ }$ & {$[18]$} & $\sqrt{ }$ \\
\hline H5 & $\begin{array}{l}\text { Online Word of Mouth (OWoM) } \\
\rightarrow \text { Trust (TR) }\end{array}$ & $\sqrt{ }$ & {$[20]$} & $\sqrt{ }$ \\
\hline H5B & $\begin{array}{l}\text { Online Word of Mouth (OWoM) } \\
\rightarrow \text { Perceived Risk (PR) }\end{array}$ & & & $\sqrt{ }$ \\
\hline
\end{tabular}

\section{CONCLUSION}

Generally, the findings from the focus group are in line with the findings in the literature. The findings from the exploratory research that are not being found from the literature reviews are the significant relationships between subjective norm (SN) and trust (TR); subjective norm (SN) and perceived risk (PR); Online Word of Mouth (OWoM) and trust (TR); Online Word of Mouth (OWoM) and perceived risk (PR). Thus, the preliminary model should be updated to analyze these relationships (Fig. 2).

The results presented in this paper will surely benefit both academics and practitioners. For the academics, the paper outlines a theoretical and a conceptual model of purchase intention as it relates to online social commerce. Opportunities exist to empirically test the model presented in the paper. For the practitioners, the constructs organized in a path model, serve as an assessment framework to evaluate current importance and identify opportunities for improvement.

\section{LIMITATIONS AND DIRECTIONS FOR FUTURE STUDIES}

Although the research findings provide some new insights to researchers, these findings should be considered in term of some limitations. The limited numbers of participants in the focus group as the sample means that the findings cannot be generalized across all different age groups of shoppers who engage in online transaction activities in the country. Two recommendations are suggested for the purpose of enhancing the study of the purchase intention in online social network. First, the sample should be increased by drawing more respondents from different regions in the country. This may enhance the validity and generalization of the research finding. Second, the final research model should be analyzed using different type of research method, such as questionnaire. In this way, a more comprehensive investigation of online purchase intention can be conducted. 


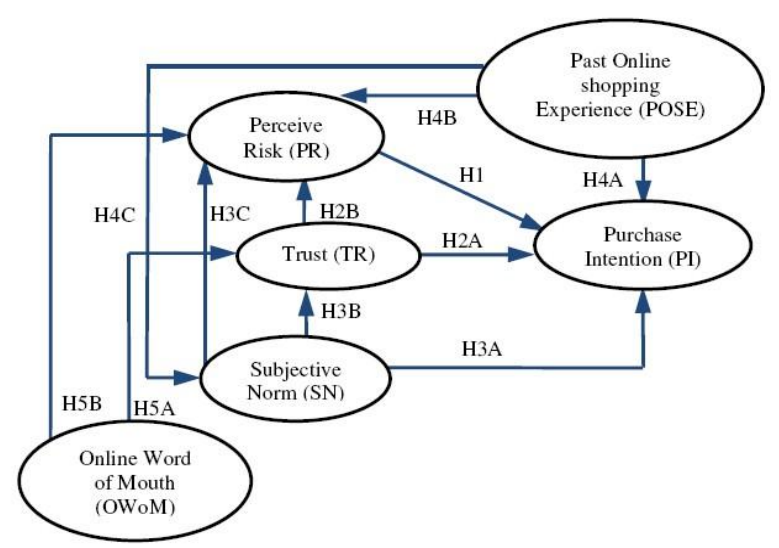

Fig. 2. Final model.

\section{REFERENCES}

[1] B. G. Silverman, M. Bachann, and K. A. Akharas, "Implications of buyer decision theory for design of ecommerce websites," International Journal of Human- Computer Studies, vol. 55, pp. 815844, 2001.

[2] R. M. O'Keefe and T. Mceachern, "Web-based customer decision support systems," Communication of The ACM, vol. 41, issue 3, pp. 71-78, 1998.

[3] R. Sinha and K. Swearingen, "Comparing recommendations made by online systems and friends," in Proceedings of the DELOS-NSF Workshop on Personalization and Recommender Systems in Digital Libraries, 2001.

[4] D. Evans, Social media marketing: an hour a day, Indianapolis, IN: Wiley Publisher, 2008.

[5] S. Nenonen, "Consumers' perceived risks in e-shopping," in Proc. the 4th International Conference on Occupational Risk Prevention 2006.

[6] H. H. Hasan and S. A. Rahim, "Factors affecting online purchasing behavior," Jurnal Komunikasi, Malaysian Jurnal of Communication, vol. 24, pp. 1- 19, 2008.

[7] P. Blau, Exchange and power in social life, New York:Wiley, 1964.

[8] D. Gefen and D. Straub, "Managing user trust in B2C e-services," $e$ Service Journal, vol. 2, no. 2, pp. 7-23, 2003.

[9] D. Kim and I. Bensabat, "Trust related arguments in internet stores: a framework for evaluation," Journal of Electronic Commerce Research, vol. 4, no. 2, pp. 49-64, 2003.

[10] V. Venkatesh and MG. Morris, "Why don't men ever stop to ask for directions? Gender, social influence, and their role in technology acceptance and usage behavior," MIS Quarterly 2000; vol. 24, no. 1, pp. 115-39, 2000.

[11] T. P. Y. Monsuwé, B. G. C. Dellart, and K. de Ruyter, "What drives consumers to shop online? A literature review," International Journal of Service Industry Management, vol. 15, no. 1, pp. 102-121, 2004.

[12] S. Shim and M. F. Drake, "Consumer intention to utilize electronic shopping," Journal of Direct Marketing, vol. 4, no. 2, pp. 22-33, 1990.

[13] J. D. Johnson, M. Meyer, M. Woodsworth, C. Ethington, and W. Stengle, "Information technologies within the Cancer Information Service:Factors related to innovation adoption," Preventive Medicine, vol. 27, Issue 5, Part A, pp. S71-S83, September 1998.

[14] H. Van der Heijden, T. Verhagen, and M. Creemers, "Understanding online purchase intentions: contributions from technology and trust perspectives," European Journal of Information Systems, vol. 12, pp. 41-48, March 2003. technology and trust perspectives," European Journal of Information Systems, vol. 12, pp. 41-48, March 2003.

[15] S. Taylor and P. A. Todd, "Understanding information technology usage: a test of competing models," Information Systems Research, vol. 6, pp. $144-176,1995$.

[16] K. Mathieson, "Predicting user intentions: comparing the technology acceptance model with theory of planned behavior," Information System Research vol. 2, no. 3, pp. 173-191, 1991.

[17] C. Ranganathan and S. Jha, "Examining Online Purchase Intentions in B2C E-Commerce: Testing an Integrated Model," Information Resources Management Journal, vol. 20, no. 4, pp. 48-64, 2007.

[18] S. Shim, M. A. Eastlick, S. L. Lotz, and P. Warrington, "An online prepurchase intentions model: the role of intention to search," Journal of Retailing, vol. 77, no. 3, pp. 397-416, 2001.

[19] Y. Hwang, and D. J. Kim, "Customer self-service systems: the effects of perceived web quality with service contents on enjoyment, anxiety, and e-trust," Decision Support Systems, vol. 43, no. 3, pp. 746-760, 2007.

[20] S. Bhatnagar Misra and H.R. Rao, "On risk, convenience, and internet shopping behavior-why some consumers are online shoppers while others are not," Communications of the ACM, vol. 43, no. 11, pp. 98$105,2000$.

[21] H. H. Kuan and G. W. Bock, "Trust transference in brick and click retailers: An investigation of the before-online-visit phase," Information and Management, vol. 44, pp. 175-187, 2007.

[22] Á. H. Crespo and I. Rodríguez del Bosque, "The effect of innovativeness on the adoption of B2C e-commerce: A model based on the Theory of Planned Behaviour," Computers in Human Behavior, vol. 24, issue 6, pp. 2830-2847, 2008.

[23] C. Park and J.-K. Jun, "A cross-cultural comparison of internet buying behavior," International Marketing Review, vol. 20, no. 5, pp. 534554, 2003.

[24] B. Yang and D. Lester, "Attitudes toward buying online," Cyberpsychology and Behavior, vol. 7, no. 1, pp. 85-92, 2004.

[25] M. L. Richins, "Word of mouth communication as negative information," in: T. Kinnear (Ed.), Advances in Consumer Research XI, Association for Consumer Research, Provo, UT, 1984.

[26] T. Yamagishi and M. Yamagishi, "Trust and commitment in the United States and Japan," Motivation and Emotion, vol.18, no. 2, pp. 129-166, 1994.

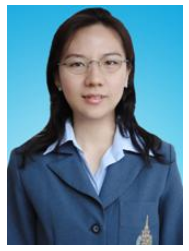

Atchara Leeraphong was born in Trang, Thailand, on May 5, 1977. She holds Master of Science (M.S. in Applied Statistics) from National Institute of Development Administration, Bangkok, Thailand and Bachelor of Science (B.Sc. in Computer Science) from Prince of Songkla University, Had-Yai, Thailand.

She is currently a Lecturer in Faculty of Commerce and Management, Prince of Songkla University (Trang Campus), Thailand. Her current research interests include ontology, semantic web, ecommerce and ebusiness.

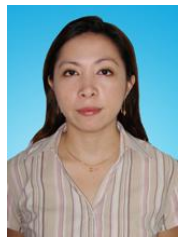

Anny Mardjo was born in Jakarta, Indonesia, on May, 1, 1976. She was awarded with Master of Information Technology from Swinburne University, Melbourne, Australia and Bachelor of Business Administration from RMIT University, Melbourne, Australia.

She is currently a Lecturer in Faculty of Commerce and Management, Prince of Songkla University (Trang Campus), Thailand. Prior that, she has worked as technical staff for Deutsche Bank internet banking in Singapore. Her research activities have focused on addressing the issue of social network, ecommerce and ebusiness. 